\title{
Penerapan Metode Discovery Learning untuk Meningkatkan Aktifitas Belajar dan Hasil Belajar Desain Grafis Percetakan pada Siswa
}

\author{
I Gusti Ngurah Bagus Aryotejo \\ SMK Negeri 1 Tampaksiring \\ Email: igusti@gmail.co.id
}

\begin{abstract}
Tujuan dari penelitian ini adalah untuk mengetahui penerapan metode discovery learning untuk meningkatkan kegiatan pembelajaran dan hasil belajar Desain Grafis Materi Gambar Bentuk dan Perspektif One-Point Missing Class XI Siswa SMK Negeri I Tampaksiring Tahun Akademik 2019/2020. Penelitian ini adalah penelitian tindakan kelas (Classroom Action Research). Penelitian dilakukan di kelas XI Sekolah Menengah Kejuruan I Tampaksiring I yang dilaksanakan mulai bulan Juni hingga Agustus 2019. Berdasarkan hasil penelitian menunjukkan bahwa penerapan metode discovery learning dapat meningkatkan aktivitas pembelajaran dan hasil belajar desain grafis mencetak data materi biasanya didistribusikan Kelas XI SMK Negeri 1 Tampaksiring 2019-2020 Tahun Akademik. Hal ini ditunjukkan oleh 1) peningkatan setiap siklus pada siklus pra-aktivitas siswa memperoleh persentase $41 \%$ termasuk dalam kategori tidak menguntungkan, pada siklus 1 persentase aktivitas siswa meningkat menjadi $72 \%$ termasuk dalam kategori cukup dan pada kedua Siklus proses meningkat menjadi lebih baik sebesar $89 \%$ termasuk dalam kategori baik. 2) Peningkatan hasil belajar siswa pada tahap pra-siklus, Siklus I, dan Siklus II meningkatkan hasil belajar. Pada tahap pra-siklus, dari 33 siswa, data diperoleh bahwa ada 25 siswa atau $76 \%$ yang mendapat skor kurang dari skor cut-off adalah 75 dan 8 siswa atau $24 \%$ yang skornya lebih dari skor cut-off adalah 75 dengan nilai rata-rata 64.84. Selanjutnya, siklus pertama dari 33 siswa memperoleh data bahwa ada 13 siswa atau 39\% yang menerima nilai kurang dari skor cut-off adalah 75 dan 20 siswa atau $61 \%$ yang nilainya lebih dari skor cut-off adalah 75 dengan nilai rata-rata 70,69, dan pada siklus kedua dari 33 siswa diperoleh data bahwa ada 4 siswa atau $12 \%$ yang mendapat skor kurang dari skor cut-off adalah 75 dan 29 siswa atau $88 \%$ yang nilainya lebih dari skor cut-off adalah 75 dengan nilai rata-rata 77.42 .
\end{abstract}

Kata Kunci: Belajar; Discoveri; Aktifitas; Hasil Belajar

\begin{abstract}
The purpose of this study was to determine the application of discovery learning methods to improve learning activities and learning outcomes Graphic Design Printing Material Picture Forms and Perspectives One-Point Missing Class XI Students of SMK Negeri I Tampaksiring Academic Year 2019/2020. This research is a class action research (Classroom Action Research). The study was conducted in class XI of Tampaksiring I Public Vocational School which was conducted from June to August 2019. Based on the results of the study showed that the application of discovery learning method can improve learning activities and learning outcomes of graphic design printing data material normally distributed Class XI SMK Negeri 1 Tampaksiring 2019-2020 Academic Year. This is indicated by 1) increasing each cycle in the pre-activity cycle of students obtained a percentage of $41 \%$ included in the unfavourable category, in cycle 1 the percentage of student activity increased to $72 \%$ included in the sufficient category and in the second cycle the process increased to be better by $89 \%$ included in either category. 2) Increased student learning outcomes in the pre-cycle stage, Cycle
\end{abstract}




\section{PEDAGOGIKA \\ Volume 11 (Nomor 1) 2020 \\ Hal. 49-61}

I, and Cycle II increased learning outcomes. In the pre-cycle stage, from 33 students, data obtained that there were 25 students or $76 \%$ who scored less than the cut-off score is 75 and 8 students or $24 \%$ whose scores were more than the cut-off score is 75 with an average value of 64.84. Furthermore, the first cycle of 33 students obtained data that there were 13 students or $39 \%$ who received grades less than the cut-off score is 75 and 20 students or $61 \%$ whose values were more than the cut-off score is 75 with an average value of 70.69 , and in the second cycle from 33 students obtained data that there are 4 students or $12 \%$ who scored less than the cut-off score is 75 and 29 students or $88 \%$ whose value was more than the cut-off score is 75 with an average value of 77.42 .

Key words: Learning; Discovery; Activity; Learning Outcome.

(C) 2020 I Gusti Ngurah Bagus Aryotejo Under The License CC-BY SA 4.0

\section{PENDAHULUAN}

Model pembelajaran yang monoton akan mengurangi motivasi siswa untuk belajar. Hal ini disebabkan karena siswa merasa jenuh dengan pola pembelajaran yang sama terus menerus. Karena itu, guru diharapkan dan mau menggunakan model pembelajaran yang lebih bervariasi yang dapat membangkitkan daya kreatifitas dan motivasi untuk belajar secara mandiri dan bekerja sama dengan siswa yang lain dalam kelompok-kelompok belajar siswa.

Metode discovery diartikan sebagai prosedur mengajar yang mementingkan pengajaran perseorang, memanipulasi objek sebelum sampai pada generalisasi. Sedangkan Bruner (dalam Sulipan, 2011) menyatakan bahwa anak harus berperan aktif didalam belajar. Lebih lanjut dinyatakan, aktivitas itu perlu dilaksanakan melalui suatu cara yang disebut discovery. Discovery yang dilaksanakan siswa dalam proses belajarnya, diarahkan untuk menemukan suatu konsep atau prinsip.

$$
\text { Discovery Learning (Pembelajaran }
$$

Penemuan) adalah metode mengajar yang mengatur pengajaran sedemikian rupa sehingga anak memperoleh pengetahuan yang sebelumnya belum diketahuinya itu tidak melalui pemberitahuan, sebagian atau seluruhnya ditemukan sendiri. Sulipan (2011) menjelaskan bahwa dalam pembelajaran discovery (penemuan) kegiatan atau pembelajaran yang dirancang sedemikian rupa sehingga siswa dapat menemukan konsep-konsep dan prinsipprinsip melalui proses mentalnya sendiri. Dalam menemukan konsep, siswa melakukan pengamatan, menggolongkan, membuat dugaan, menjelaskan, menarik kesimpulan dan sebagainya untuk menemukan beberapa konsep atau prinsip.

Belajar tidak ada warnanya apabila tidak menghasilkan pengetahuan, pembentukan sikap serta keterampilan. 
PEDAGOGIKA

Volume 11 (Nomor 1) 2020

Hal. 49-61

Oleh karena itu, proses belajar mengajar harus mendapat perhatian yang serius yang melibatkan berbagai aspek yang menunjang keberhasilan belajar mengajar. Benyamin Bloom secara garis besar mengklasifikasikan hasil belajar menjadi 3 ranah, yakni ranah kognitif, afektif dan psikomotorik. Berikut adalah penjelasan aspek tersebut :

1) Ranah kognitif

Ranah kognitif berkenaan dengan hasil belajar intelektual yang terdiri dari enam aspek, yakni pengetahuan atau ingatan, pemahaman, aplikasi, analisis, sintesis dan evaluasi.

2) Ranah afektif

Ranah afektif berkenaan dengan sikap dan nilai yang terdiri dari penerimaan, jawaban, reaksi, dan organisasi.

3) Ranah psikomotorik

Ranah psikomotorik berkenaan dengan hasil belajar keterampilan dan kemampuan bertindak individu yang terdiri dari lima aspek, yakni gerakan refleks, keterampilan gerakan dasar, kemampuan keharmonisan atau ketepatan, gerakan keterampilan kompleks dan gerakan ekspresif.
Ketiga ranah hasil belajar tersebut sangat penting diketahui oleh seorang guru dalam merumuskan tujuan pengajaran dan menyusun alatalat penilaian, baik tes maupun bukan tes.

\section{METODE PENELITIAN}

Penjelasan alur Desain Penelitian Tindakan Kelas di atas adalah:

1. Perencanaan awal, sebelum mengadakan penelitian peneliti menyusun rumusan masalah, tujuan dan membuat rencana tindakan, termasuk didalamnya instrumen penelitian dan perangkat pembelajaran.

2. Tindakan dan observasi, meliputi tindakan yang dilakukan oleh peneliti dengan peran sebagai upaya mengetahui proses pelaksanaan tindakan metode pembelajaran yang diterapkan dalam hal ini adalah metode Discovery Learning pada mata pelajaran desain grafis percetakan. Dari hasil observasi ini didapatkan hasil dari focus masalah yang ingin dipecahkan yaitu hasil belajar desain grafis percetakan pada materi Gambar bentuk dan perspektif satu titik hilang siswa kelas XI tahun pelajaran 2019/2020 .

3. Refleksi, peneliti mengkaji, melihat dan mempertimbangkan hasil atau dampak dari tindakan yang dilakukan 
PEDAGOGIKA

Volume 11 (Nomor 1) 2020

Hal. 49-61

berdasarkan lembar pengamatan atau lembar observasi yang diisi oleh pengamat.

4. Perbaikan rencana, berdasarkan hasil refleksi dari pengamat membuat rancangan yang direvisi untuk dilaksanakan pada siklus berikutnya.

Penelitian ini dilaksanakan selama dua siklus. Observasi dibagi dalam dua siklus, dimana masing-masing siklus dikenai perlakuan yang sama (alur kegiatan yang sama) dan membahas satu sub pokok bahasan yang diakhiri dengan tes di akhir masing-masing siklus untuk mengetahui hasil dari pelaksanaan tindakan. Dibuat dalam dua siklus dimaksudkan untuk memperbaiki sistem pengajaran yang telah dilaksanakan.

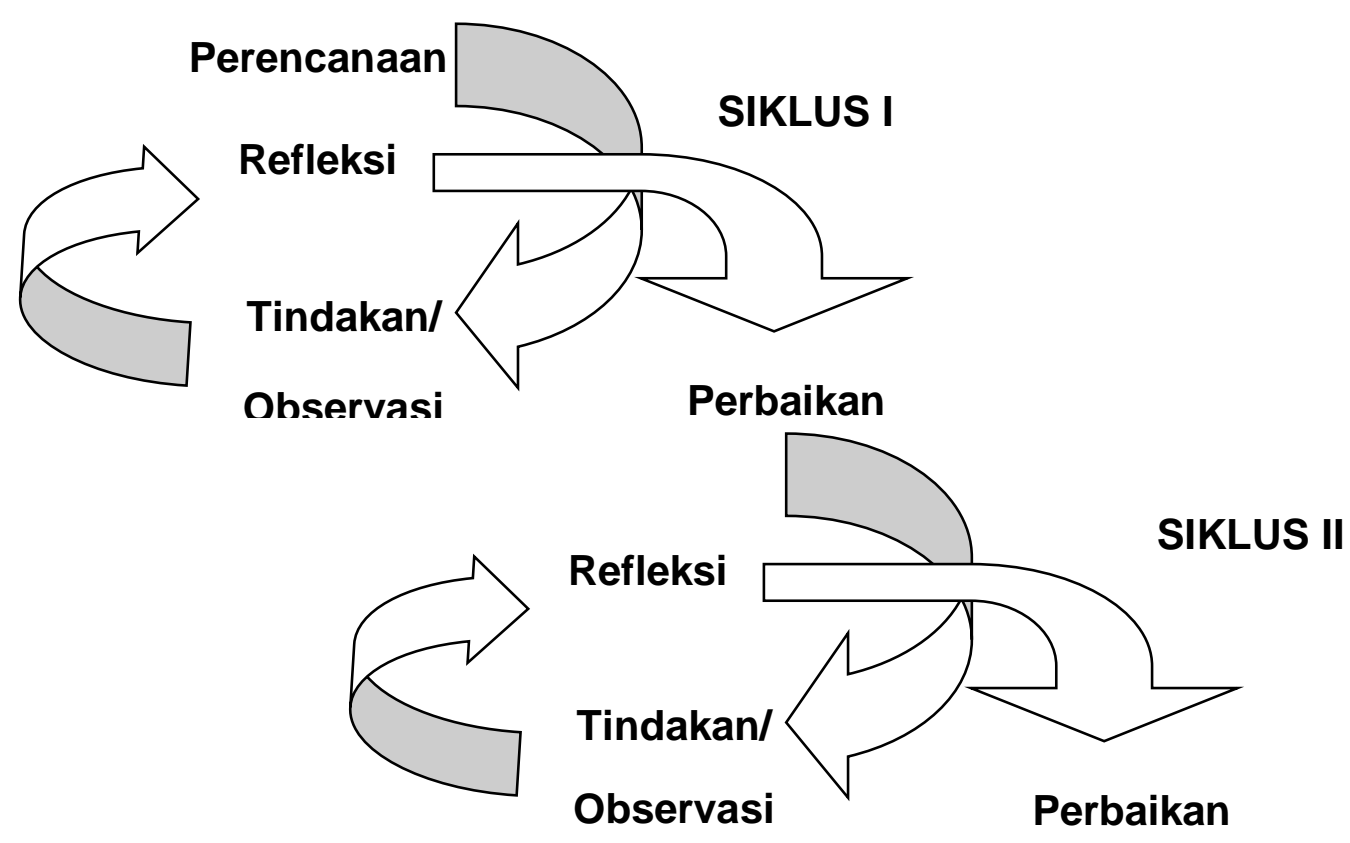

Gambar 1. Siklus Penelitian Tindakan Kelas

HASIL PENELITIAN DAN PEMBAHASAN

Berdasarkan menunjukan bahwa hasil penelitian penerapan Metode discovery learning dapat meningkatkan aktivitas belajar dan hasil belajar desain grafis percetakan materi Data berdistribusi normal Kelas XI SMK Negeri 1
Tampaksiring Tahun Pelajaran 20192020. Hal tersebut ditunjukan dengan 1) meningkat setiap siklusnya pada prasiklus aktivitas siswa diperoleh presentase sebesar $41 \%$ masuk pada kategori kurang baik, pada siklus 1 prosentase aktivitas siswa meningkat menjadi $72 \%$ masuk dalam kategori cukup dan pada siklus II 
PEDAGOGIKA

Volume 11 (Nomor 1) 2020

Hal. 49-61

prosesntase meningkat menjadi lebih baik sebesar $89 \%$ masuk dalam kategori baik. 2) Meningkatnya hasil belajar siswa pada tahap pra siklus, Siklus I, dan Siklus II mengalami kenaikan hasil belajar. Pada tahap prasiklus yaitu dari 33 siswa diperoleh data bahwa terdapat 25 siswa atau $76 \%$ yang memperoleh nilai kurang dari KKM 75 dan 8 atau $24 \%$ siswa yang nilainya lebih dari KKM 75 dengan nilai rata-rata sebesar 64.84. Selanjutnya siklus
I dari 33 siswa diperoleh data bahwa terdapat 13 siswa atau $39 \%$ anak yang memperoleh nilai kurang dari KKM 75 dan 20 siswa atau $61 \%$ yang nilainya lebih dari KKM 75 dengan nilai rata-rata sebesar 70.69, dan pada siklus II dari 33 siswa diperoleh data bahwa terdapat 4 siswa atau $12 \%$ yang memperoleh nilai kurang dari KKM 75 dan 29 siswa atau $88 \%$ yang nilainya lebih dari KKM 75 dengan nilai rata-rata

77.42

Tabel 1. Hasil Belajar Prasiklus siswa Kelas XI SMK Negeri 1 Tampaksiring tahun pelajaran 2019/2020

\begin{tabular}{|c|c|c|c|c|}
\hline No & Nama & Jenis Kelamin & Nilai & Keterangan \\
\hline 1 & Siswa 1 & $\mathrm{~L}$ & 60 & Tidak Lulus \\
\hline 2 & Siswa 2 & $\mathrm{P}$ & 70 & Tidak Lulus \\
\hline 3 & Siswa 3 & $\mathrm{P}$ & 65 & Tidak Lulus \\
\hline 4 & Siswa 4 & $\mathrm{~L}$ & 60 & Tidak Lulus \\
\hline 5 & Siswa 5 & $\mathrm{P}$ & 65 & Tidak Lulus \\
\hline 6 & Siswa 6 & $\mathrm{P}$ & 55 & Tidak Lulus \\
\hline 7 & Siswa 7 & $\mathrm{~L}$ & 75 & Lulus \\
\hline 8 & Siswa 8 & $\mathrm{P}$ & 55 & Tidak Lulus \\
\hline 9 & Siswa 9 & $\mathrm{~L}$ & 50 & Tidak Lulus \\
\hline 10 & Siswa 10 & $\mathrm{P}$ & 75 & Lulus \\
\hline 11 & Siswa 11 & $\mathrm{P}$ & 50 & Tidak Lulus \\
\hline 12 & Siswa 12 & $\mathrm{P}$ & 65 & Tidak Lulus \\
\hline 13 & Siswa 13 & $\mathrm{P}$ & 55 & Tidak Lulus \\
\hline 14 & Siswa 14 & $\mathrm{P}$ & 70 & Tidak Lulus \\
\hline 15 & Siswa 15 & $\mathrm{P}$ & 70 & Tidak Lulus \\
\hline 16 & Siswa 16 & $\mathrm{~L}$ & 55 & Tidak Lulus \\
\hline 17 & Siswa 17 & $\mathrm{~L}$ & 80 & Lulus \\
\hline 18 & Siswa 18 & $\mathrm{~L}$ & 60 & Tidak Lulus \\
\hline 19 & Siswa 19 & $\mathrm{~L}$ & 80 & Lulus \\
\hline 20 & Siswa 20 & $\mathrm{P}$ & 60 & Tidak Lulus \\
\hline 21 & Siswa 21 & $\mathrm{~L}$ & 60 & Tidak Lulus \\
\hline 22 & Siswa 22 & $\mathrm{P}$ & 75 & Lulus \\
\hline 23 & Siswa 23 & $\mathrm{~L}$ & 60 & Tidak Lulus \\
\hline 24 & Siswa 24 & $\mathrm{P}$ & 80 & Lulus \\
\hline 25 & Siswa 25 & $\mathrm{P}$ & 70 & Tidak Lulus \\
\hline 26 & Siswa 26 & $\mathrm{P}$ & 55 & Tidak Lulus \\
\hline 27 & Siswa 27 & $\mathrm{P}$ & 60 & Tidak Lulus \\
\hline & Pedagogika.fip@ung.ac.id & P-ISSN : 2086-4469 & \multicolumn{2}{|c|}{ E-ISSN : 2716-0580 } \\
\hline
\end{tabular}


PEDAGOGIKA

Volume 11 (Nomor 1) 2020

Hal. 49-61

\begin{tabular}{clccc}
\hline 28 & Siswa 28 & L & 60 & Tidak Lulus \\
\hline 29 & Siswa 29 & P & 75 & Lulus \\
\hline 30 & Siswa 30 & P & 55 & Tidak Lulus \\
\hline 31 & Siswa 31 & P & 70 & Tidak Lulus \\
\hline 32 & Siswa 32 & P & 65 & Tidak Lulus \\
\hline 33 & Siswa 33 & L & 80 & Lulus \\
\hline & Jumlah & & $\mathbf{2 1 4 0}$ & \\
& Rata-rata & & $\mathbf{6 4 . 8 4}$ &
\end{tabular}

Tabel 2. Prosentase Ketuntasan

\begin{tabular}{cccc}
\hline No & No Kategori & Jumlah Siswa & Persentase (\%) \\
& & 8 & 24 \\
\hline 1 & Tuntas dengan nilai $\geq 75$ & 25 & 76 \\
\hline 2 & Tidak tuntas dengan skor $<75$ & $\mathbf{3 3}$ siswa & $\mathbf{1 0 0 \%}$
\end{tabular}

Tabel 3. Pengamatan Aktivitas Prasiklus

\begin{tabular}{clcc}
\hline No & \multicolumn{1}{c}{ Aktivitas } & Jumlah Siswa & Presentase \\
\hline 1 & Mendengarkan penjelasan guru & 17 & $52 \%$ \\
\hline 2 & Mencatat materi penjelasan & 15 & $45 \%$ \\
\hline 3 & Bertanya dan menjawab & 12 & $36 \%$ \\
\hline 4 & Aktif dalam diskusi & 12 & $36 \%$ \\
\hline 5 & Menyumbang ide dalam diskusi & 13 & $39 \%$ \\
\hline 6 & Bekerjasama dalam kelompok & 13 & $39 \%$ \\
\hline & Rata-rata & & $\mathbf{4 1 \%}$ \\
\hline & Kategori & & kurang sekali \\
\hline
\end{tabular}

Tabel 4. Kriteria Taraf Keberhasilan Tindakan

\begin{tabular}{cc}
\hline Tingkat penguasaan & Predikat \\
\hline $91 \% \leq \mathrm{NR} \leq 100 \%$ & Sangat baik \\
\hline $81 \% \leq \mathrm{NR} \leq 90 \%$ & Baik \\
\hline $71 \% \leq \mathrm{NR} \leq 80 \%$ & Cukup \\
\hline $60 \% \leq \mathrm{NR} \leq 70 \%$ & Kurang \\
\hline $0 \% \leq \mathrm{NR} \leq 50 \%$ & Kurang Sekali \\
\hline
\end{tabular}


PEDAGOGIKA

Volume 11 (Nomor 1) 2020

Hal. 49-61

Tabel 5. Hasil Aktivitas Siswa Siklus I

\begin{tabular}{clcc}
\hline No & \multicolumn{1}{c}{ Aktivitas } & Jumlah Siswa & Presentase \\
\hline 1 & Mendengarkan penjelasan guru & 26 & $79 \%$ \\
\hline 2 & Mencatat materi penjelasan & 24 & $73 \%$ \\
\hline 3 & Bertanya dan menjawab & 23 & $70 \%$ \\
\hline 4 & Aktif dalam diskusi & 21 & $64 \%$ \\
\hline 5 & Menyumbang ide dalam diskusi & 24 & $73 \%$ \\
\hline 6 & Bekerjasama dalam kelompok & 25 & $76 \%$ \\
\hline & Rata-rata & & $\mathbf{7 2 \%}$ \\
\hline & Kategori & & cukup \\
\hline
\end{tabular}

Tabel 6. Kriteria Taraf Keberhasilan Tindakan

\begin{tabular}{lc}
\hline Tingkat penguasaan & Predikat \\
\hline $91 \% \leq \mathrm{NR} \leq 100 \%$ & Sangat baik \\
\hline $81 \% \leq \mathrm{NR} \leq 90 \%$ & Baik \\
\hline $71 \% \leq \mathrm{NR} \leq 80 \%$ & Cukup \\
\hline $60 \% \leq \mathrm{NR} \leq 70 \%$ & Kurang \\
\hline $0 \% \leq \mathrm{NR} \leq 50 \%$ & Kurang Sekali \\
\hline
\end{tabular}

Tabel 7. Hasil Belajar tahap Siklus I siswa Kelas XI SMK Negeri 1 Tampaksiring Tahun Pelajaran 2019/2020

\begin{tabular}{clcccl}
\hline No & & Siswa & Jenis Kelamin & Nilai & \multicolumn{1}{c}{ Keterangan } \\
\hline 1 & Siswa 1 & L & 65 & Tidak Lulus \\
\hline 2 & Siswa 2 & P & 75 & Lulus \\
\hline 3 & Siswa 3 & P & 70 & Tidak Lulus \\
\hline 4 & Siswa 4 & L & 75 & Lulus \\
\hline 5 & Siswa 5 & P & 75 & Lulus \\
\hline 6 & Siswa 6 & P & 80 & Lulus \\
\hline 7 & Siswa 7 & L & 80 & Lulus \\
\hline 8 & Siswa 8 & P & 65 & Tidak Lulus \\
\hline 9 & Siswa 9 & L & 60 & Tidak Lulus \\
\hline 10 & Siswa 10 & P & 80 & Lulus \\
\hline 11 & Siswa 11 & P & 55 & Tidak Lulus \\
\hline 12 & Siswa 12 & P & 70 & Tidak Lulus \\
\hline 13 & Siswa 13 & P & 60 & Tidak Lulus \\
\hline 14 & Siswa 14 & P & 75 & Lulus \\
\hline 15 & Siswa 15 & P & 80 & Lulus \\
\hline 16 & Siswa 16 & L & 70 & Tidak Lulus \\
\hline 17 & Siswa 17 & L & 80 & Lulus \\
\hline
\end{tabular}

Pedagogika.fip@ung.ac.id P-ISSN : 2086-4469 E-ISSN : 2716-0580 
PEDAGOGIKA

Volume 11 (Nomor 1) 2020

Hal. 49-61

\begin{tabular}{lllll}
\hline 18 & Siswa 18 & L & 75 & Lulus \\
\hline 19 & Siswa 19 & L & 75 & Lulus \\
\hline 20 & Siswa 20 & P & 60 & Tidak Lulus \\
\hline 21 & Siswa 21 & L & 65 & Tidak Lulus \\
\hline 22 & Siswa 22 & P & 80 & Lulus \\
\hline 23 & Siswa 23 & L & 65 & Tidak Lulus \\
\hline 24 & Siswa 24 & P & 85 & Lulus \\
\hline 25 & Siswa 25 & P & 80 & Lulus \\
\hline 26 & Siswa 26 & P & 80 & Lulus \\
\hline 27 & Siswa 27 & P & 75 & Lulus \\
\hline 28 & Siswa 28 & L & 65 & Tidak Lulus \\
\hline 29 & Siswa 29 & P & 80 & Lulus \\
\hline 30 & Siswa 30 & P & 65 & Tidak Lulus \\
\hline 31 & Siswa 31 & P & 75 & Lulus \\
\hline 32 & Siswa 32 & P & 75 & Lulus \\
\hline 33 & Siswa 33 & L & 85 & Lulus \\
\hline & Jumlah & & $\mathbf{2 4 0 0}$ & \\
\hline & Rata-rata & & $\mathbf{7 0 . 6 9}$ &
\end{tabular}

Tabel 8. Prosentase Ketuntasan

\begin{tabular}{llcc}
\hline No & \multicolumn{1}{c}{ No Kategori } & Jumlah Siswa & Persentase $(\%)$ \\
\hline 1 & Tuntas dengan nilai $\geq 75$ & 20 & 61 \\
\hline 2 & Tidak tuntas dengan skor $<75$ & 13 & 39 \\
\hline & Total & $\mathbf{3 3}$ & $\mathbf{1 0 0}$ \\
\hline
\end{tabular}

Tabel 9. Hasil Aktivitas Siswa Siklus II

\begin{tabular}{clcc}
\hline No & \multicolumn{1}{c}{ Aktivitas } & Jumlah Siswa & Presentase \\
\hline 1 & Mendengarkan penjelasan guru & 32 & $97 \%$ \\
\hline 2 & Mencatat materi penjelasan & 30 & $91 \%$ \\
\hline 3 & Bertanya dan menjawab & 29 & $88 \%$ \\
\hline 4 & Aktif dalam diskusi & 29 & $88 \%$ \\
\hline 5 & Menyumbang ide dalam diskusi & 26 & $79 \%$ \\
\hline 6 & Bekerjasama dalam kelompok & 30 & $91 \%$ \\
\hline & Rata-rata & & $\mathbf{8 9 \%}$ \\
\hline & Kategori & & Baik \\
\hline
\end{tabular}

Tabel 10. Kriteria Taraf Keberhasilan Tindakan

Tingkat penguasaan Predikat

\begin{tabular}{lc}
\hline $91 \% \leq \mathrm{NR} \leq 100 \%$ & Sangat baik \\
\hline $81 \% \leq \mathrm{NR} \leq 90 \%$ & Baik \\
\hline $71 \% \leq \mathrm{NR} \leq 80 \%$ & Cukup \\
\hline $60 \% \leq \mathrm{NR} \leq 70 \%$ & Kurang \\
\hline $0 \% \leq \mathrm{NR} \leq 50 \%$ & Kurang Sekali \\
\hline
\end{tabular}

Pedagogika.fip@ung.ac.id P-ISSN : 2086-4469 E-ISSN : 2716-0580 
PEDAGOGIKA

Volume 11 (Nomor 1) 2020

Hal. 49-61

Tabel 11. Hasil Belajar Siklus II siswa Kelas XI SMK Negeri 1 Tampaksiring Tahun Pelajaran 2019/2020

\begin{tabular}{|c|c|c|c|c|}
\hline No & Siswa & Jenis Kelamin & Nilai & Keterangan \\
\hline 1 & Siswa 1 & $\mathrm{~L}$ & 75 & Lulus \\
\hline 2 & Siswa 2 & $\mathrm{P}$ & 80 & Lulus \\
\hline 3 & Siswa 3 & $\mathrm{P}$ & 75 & Lulus \\
\hline 4 & Siswa 4 & $\mathrm{~L}$ & 80 & Lulus \\
\hline 5 & Siswa 5 & $\mathrm{P}$ & 80 & Lulus \\
\hline 6 & Siswa 6 & $\mathrm{P}$ & 85 & Lulus \\
\hline 7 & Siswa 7 & $\mathrm{~L}$ & 85 & Lulus \\
\hline 8 & Siswa 8 & $\mathrm{P}$ & 70 & Tidak Lulus \\
\hline 9 & Siswa 9 & $\mathrm{~L}$ & 60 & Tidak Lulus \\
\hline 10 & Siswa 10 & $\mathrm{P}$ & 85 & Lulus \\
\hline 11 & Siswa 11 & $\mathrm{P}$ & 60 & Tidak Lulus \\
\hline 12 & Siswa 12 & $\mathrm{P}$ & 75 & Lulus \\
\hline 13 & Siswa 13 & $\mathrm{P}$ & 75 & Lulus \\
\hline 14 & Siswa 14 & $\mathrm{P}$ & 80 & Lulus \\
\hline 15 & Siswa 15 & $\mathrm{P}$ & 80 & Lulus \\
\hline 16 & Siswa 16 & $\mathrm{~L}$ & 75 & Lulus \\
\hline 17 & Siswa 17 & $\mathrm{~L}$ & 85 & Lulus \\
\hline 18 & Siswa 18 & $\mathrm{~L}$ & 80 & Lulus \\
\hline 19 & Siswa 19 & $\mathrm{~L}$ & 80 & Lulus \\
\hline 20 & Siswa 20 & $\mathrm{P}$ & 75 & Lulus \\
\hline 21 & Siswa 21 & $\mathrm{~L}$ & 75 & Lulus \\
\hline 22 & Siswa 22 & $\mathrm{P}$ & 85 & Lulus \\
\hline 23 & Siswa 23 & $\mathrm{~L}$ & 70 & Tidak Lulus \\
\hline 24 & Siswa 24 & $\mathrm{P}$ & 85 & Lulus \\
\hline 25 & Siswa 25 & $\mathrm{P}$ & 80 & Lulus \\
\hline 26 & Siswa 26 & $\mathrm{P}$ & 85 & Lulus \\
\hline 27 & Siswa 27 & $\mathrm{P}$ & 80 & Lulus \\
\hline 28 & Siswa 28 & $\mathrm{~L}$ & 65 & Lulus \\
\hline 29 & Siswa 29 & $\mathrm{P}$ & 80 & Lulus \\
\hline 30 & Siswa 30 & $\mathrm{P}$ & 75 & Lulus \\
\hline 31 & Siswa 31 & $\mathrm{P}$ & 80 & Lulus \\
\hline 32 & Siswa 32 & $\mathrm{P}$ & 65 & Lulus \\
\hline \multirow[t]{3}{*}{33} & Siswa 33 & $\mathrm{~L}$ & 90 & Lulus \\
\hline & Jumlah & & 2555 & \\
\hline & Rata-rata & & 77.42 & \\
\hline
\end{tabular}


PEDAGOGIKA

Volume 11 (Nomor 1) 2020

Hal. 49-61

Tabel 12. Prosentase Ketuntasan

\begin{tabular}{llcc}
\hline No & \multicolumn{1}{c}{ No Kategori } & Jumlah Siswa & Persentase (\%) \\
\hline 1 & Tuntas dengan nilai $\geq 75$ & 29 & 88 \\
\hline 2 & Tidak tuntas dengan skor $<75$ & 4 & 12 \\
\hline \multicolumn{2}{r}{ Total } & 33 siswa & 100 \\
\hline
\end{tabular}

Diagaram 1. Hasil Belajar tahap Prasiklus Siswa Kelas XI SMK Negeri 1

Tampaksiring Tahun pelajar 2019/2020

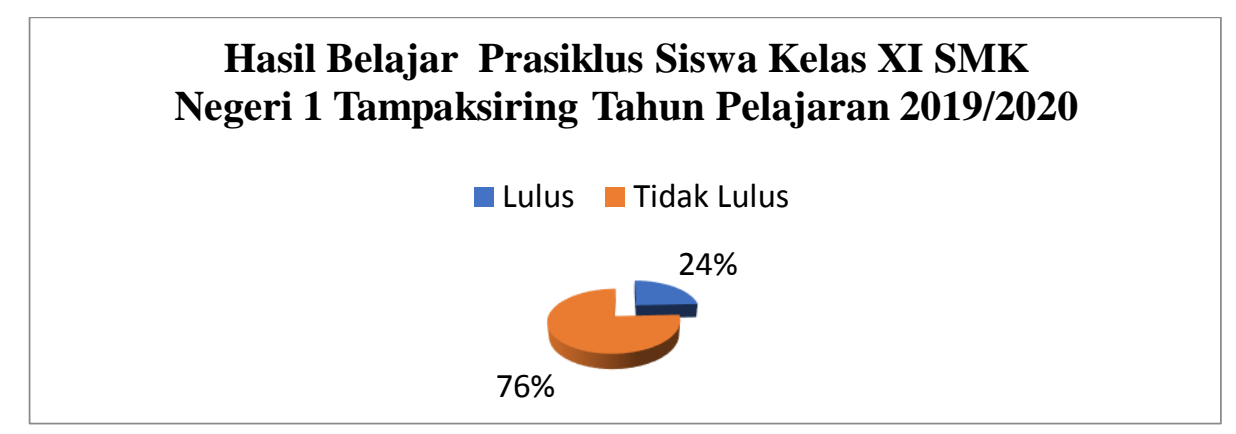

Diagram 2. Hasil Belajar Siklus I Siswa Kelas XI SMK Negeri 1 Tampaksiring Tahun Pelajaran 2019/2020

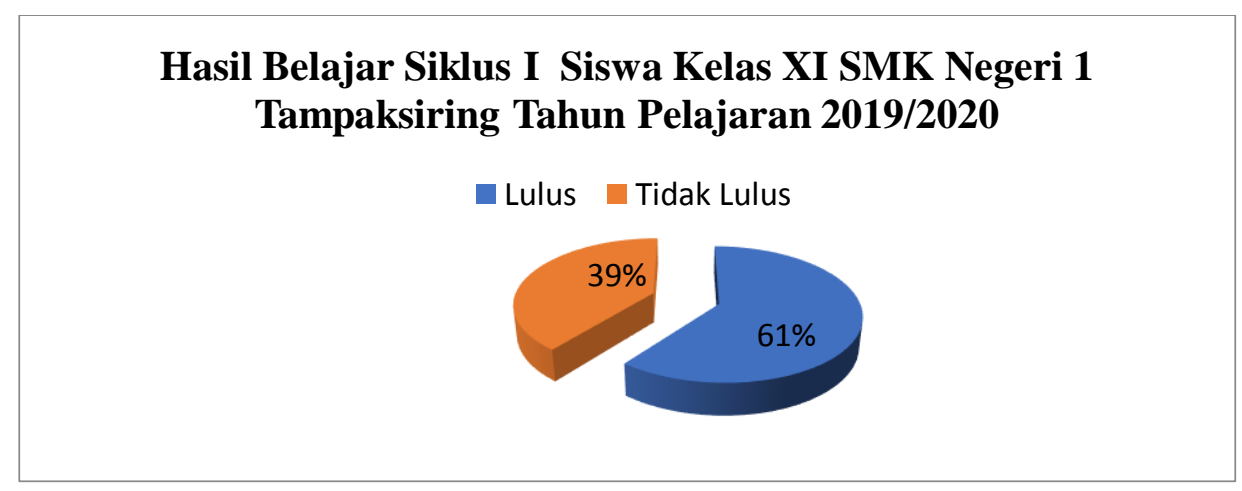

Diagram 3. Hasil Belajar siklus II Siswa Kelas XI SMK Negeri 1 Tampaksiring Tahun Pelajaran 2019/2020

Hasil Belajar Siklus II Siswa Kelas XI SMK Negeri 1

Tampaksiring Tahun Pelajaran 2019/2020

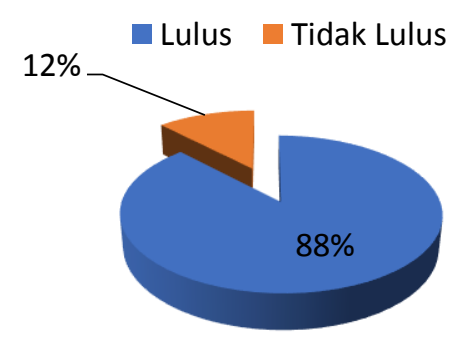




\section{PEDAGOGIKA}

Volume 11 (Nomor 1) 2020

Hal. 49-61

Metode penemuan adalah terjemahan dari discovery. Menurut Sund discovery adalah proses mental dimana siswa mampu mengasimilasikan sesuatu konsep atau prinsip. Proses mental tersebut antara lain ialah mengamati, mencerna, mengerti, menggolongkan, membuat dugaan, menjelaskan, mengukur membuat kesimpulan dan sebagainya. Suatu konsep misalnya segitiga, demokrasi dan sebagainya, sedang yang dimaksud dengan prisnsip antara lain ialah logam apabila dipanaskan akan mengembang. Dalam metode ini siswa dibiarkan menemukan sendiri atau mengalami proses mental itu sendiri, guru hanya membimbing dan memberikan instruksi.

Dalam penelitian yang dilakukan oleh peneliti dibagi menjadi dua siklus dalam kegiatan proses belajar. Dengan data yang dikumpul mencakup aktivitas guru, aktivitas siswa, dan hasil belajar. Dari data hasil mewawancarai peserta didik. Dengan siklus I dan II, dari hasil penelitian dengan menggunakan model discovery learning dari pembelajaran desain grafis percetakan

Dalam menyiapkan pembelajaran pada siklus I dan II yaitu : 1) deangan menganalisis kurikulum, 2) rencana pelaksanaan pembelajaran ( RPP ) menggunakan model pembelajaran discovery learning, 3) sumber dan media dalam pembelajran, 4) lembar kerja siswa ( LKS ), 5) dengan menentukan instrument penelitian, 6) dengan mengevaluasi kriteria indicator dalam keberhasilan. Pada tahapan siklus I dan II peneliti dinyatakan berhasil dengan baik pada proses pembelajaran yang dengan aktivitas guru dan aktivitas peserta didik dengan pencapaian keberhasilan $80 \%$.

Metode discovery learning adalah suatu pembelajaran yang mengutamakan objek, manipulasi, perseorangan dan juga diuji coba. ( suryosubroto, 2002) dalam kaitannya dengan pendidikan, (Oemar malik, 2012) menyakakan bahwa discovery adalah proses pembelajaran yang menitik beratkan pada mental intelektual pada anak didik dalam memecahkan barbagai persoalan yang dihadapi, sehingga menemukan suatu konsep yang dapat diterapkan dilapangan. Hasil belajar dengan menerapkan model pembelajaran discovery learning dalam penelitian ini yang dicapai berupa aspek kognitif setelah siswa diberi tes, aspek afektif dapat dinilai dari proses pembelajaran.Selain itu hasil penelitian Gusmaweti menunjukan hasil belajar siswa dengan model pembelajaran discovery learning lebih tinggi dari hasil belajar siswa 
PEDAGOGIKA

Volume 11 (Nomor 1) 2020

Hal. 49-61

dengan model pembelajaran secara langsung.

\section{KESIMPULAN}

Berdasarkan hasil penelitian menunjukan bahwa penerapan Metode discovery learning dapat meningkatkan aktivitas belajar dan hasil belajar desain grafis percetakan materi Data berdistribusi normal Kelas XI SMK Negeri 1 Tampaksiring Tahun Pelajaran 20192020. Hal tersebut ditunjukan dengan 1) meningkat setiap siklusnya pada prasiklus aktivitas siswa diperoleh presentase sebesar 41\% masuk pada kategori kurang baik , pada siklus 1 prosentase aktivitas siswa meningkat menjadi $72 \%$ masuk dalam kategori cukup dan pada siklus II prosesntase meningkat menjadi lebih baik sebesar $89 \%$ masuk dalam kategori baik. 2) Meningkatnya hasil belajar siswa pada tahap pra siklus, Siklus I, dan Siklus II mengalami kenaikan hasil belajar. Pada tahap prasiklus yaitu dari 33 siswa diperoleh data bahwa terdapat 25 siswa atau $76 \%$ yang memperoleh nilai kurang dari KKM 75 dan 8 atau $24 \%$ siswa yang nilainya lebih dari KKM 75 dengan nilai rata-rata sebesar 64.84. Selanjutnya siklus I dari 33 siswa diperoleh data bahwa terdapat 13 siswa atau $39 \%$ anak yang memperoleh nilai kurang dari KKM 75 dan 20 siswa atau $61 \%$ yang nilainya lebih dari KKM 75

dengan nilai rata-rata sebesar 70.69, dan pada siklus II dari 33 siswa diperoleh data bahwa terdapat 4 siswa atau $12 \%$ yang memperoleh nilai kurang dari KKM 75 dan 29 siswa atau $88 \%$ yang nilainya lebih dari KKM 75 dengan nilai rata-rata sebesar 77.42 .

\section{REFERENSI}

Abas.2011. Upaya Meningkatkan Minat Belajar Siswa Melalui Metode Pembelajaran Discovery Learning di SDN Koleang 03. Karya Tulis Ilmiah tidak diterbitkan. Bogor: Universitas Muhammadiyah Prof. Dr. Hamka

Ali, Muhammad.2007. Guru dalam Proses Belajar Mengajar. Bandung: Sinar baru Algesindo.

Amirin, Tatang M. 2011. Taksonomi Bloom Versi Baru.

(Online).(http://tatangmanguny.wor dpres.com/2011/02/03/taksonomibloom-versi-baru-2) diakses tanggal 20 maret 2014.

Aprilia, Fifin. 2012. Meningkatkan aktivitas dan hasil belajar siswa pada pembelajaran ipa tentang kenampakan matahari dengan pendekatan discovery: penelitian tindakan kelas pada siswa kelas ii di sd negeri 2 cibogo kecamatan lembang kabupaten bandung barat. Skripsi tidak diterbitkan.Bandung: Perpustakaan UPI.

Aqib,Z. (2010). Penelitian Tindakan Kelas. Bandung:Yrama.

Arikunto, Suharsimi. (2010). Prosedur Penelitian Suatu Pendekatan Praktik. Yogyakarta: Rineka Cipta. 


\section{PEDAGOGIKA}

Volume 11 (Nomor 1) 2020

Hal. 49-61

Arikunto, Suharsimi. (2011). Penelitian Tindakan Kelas. Jakarta: PT. Bumi Aksara.

Arikunto, Suharsimi. 2006. Prosedur Penelitian suatu Pendekatan Praktik Edisi Revisi VI. Jakarta: Rineka Cipta.

Depdiknas.2004.Kurikulum.(Online).http:// www.puskur.net/inc/si/sma/ desain grafis.pdf diakses tanggal 15 Januari 2008

Faridah. 2010. Efektivitas metode pembelajaran inquiry Discovery learning terhadap hasil belajar Mata pelajaran pai pada siswa kelas VIII Semester 1 SMP NU 01 Muallimin Weleri Tahun pelajaran 2010-2011. Skripsi tidak diterbitkan.Semarang: Institut Agama Islam Negeri Walisongo.

Hanafiah, Nanang. (2010). Konsep Strategi Pembelajaran. Bandung: PT Reflika Aditama.

Herman Hudojo. 2003. Pengembangan Kurikulum dan Pembelajaran. Malang: FMIPA Universitas Negeri Malang.

Hernawan, Asep Herry, dkk (2008). Materi Pokok Pembelajaran Terpadu di SD. Jakarta: Universitas Terbuka. 